\title{
FORMULATION AND EVALUATION OF EFFERVESCENT GRANULES OF IBUPROFEN
}

\author{
JINAN AL-MOUSAWY'1, ZAHRAA AL-HUSSAINY ${ }^{1}$, MARYAM ALAAYEDI ${ }^{1}$
}

${ }^{1}$ College of Pharmacy/University of Kerbala, Kerbala, Iraq

Email: jinan.mousawy@uokerbala.edu.iq

Received: 14 Jul 2019, Revised and Accepted: 27 Aug 2019

\section{ABSTRACT}

Objective: The object of this investigation was to formulate and evaluate effervescent granules of ibuprofen, to increase its dissolution rate to get rapid analgesic and antipyretic effects.

Methods: Five formulas (F1-F5) of effervescent ibuprofen granules were formulated by the wet granulation method. Croscarmellose sodium, powder of banana and other ingredients were used in the formulation of effervescent granules. Evaluation studies were carried out for all five formulas, these include: (compatibility study, flowability study, \% of drug content, effervescent time and in vitro dissolution study).

Results: The results show that the formulated granules have good flow properties with suitable bulk density for the uniting dose. FTIR study shows that there is no drug interaction with other ingredients in the formula. All five formulas have effervescent time less than 3 min, F5 show the best drug release $99.1 \pm 1$ and effervescent time about 80 sec.

Conclusion: Ibuprofen was successfully formulated and evaluated as effervescent granules by using a combination of croscarmellose sodium and banana powder.

Keywords: Ibuprofen, Effervescent, Granules, Wet granulation

(C) 2019 The Authors. Published by Innovare Academic Sciences Pvt Ltd. This is an open-access article under the CC BY license (http://creativecommons.org/licenses/by/4.0/) DOI: http://dx.doi.org/10.22159/ijap.2019v11i6.34912

\section{INTRODUCTION}

Effervescent granulates are one of the most popular oral dosage forms; most of the pharmaceutical products like analgesics, antacid and cough formulation were prepared as effervescent granules. Effervescent granules are soluble, dissolve quickly and provide a palatable formula which can avoid the bad bitter taste of drugs. It is convenient, stable dosage forms [1].

The addition of effervescent granules into a cup contains $250 \mathrm{ml}$ of water exactly before taking by the patient, the granules will be dispersed readily in the water, and they are dissolved by releasing of carbon dioxide gas. This occurs due to the interaction between acidic ingredients and basic bicarbonates in the presence of water. The libration of carbon dioxide will enhance the dissolution of the drug and mask the bitter taste effect of the drug [2]. Ibuprofen is a propionic acid derivative. It's a non-steroidal anti-inflammatory agent used for treating rheumatoid arthritis and osteoarthritis. Ibuprofen considers insoluble substance in water $(0.078 \mu \mathrm{g} / \mathrm{ml})$ with $\mathrm{pKa} 4.5$. Due to the low solubility of ibuprofen, the dissolution profile of ibuprofen may be considering the rate-limiting step for the absorption process of the ibuprofen drug [3].
This study aimed to enhance the release profile of ibuprofen by using the wet granulation method to prepare effervescent granules of ibuprofen.

\section{MATERIALS AND METHODS}

Ibuprofen (Samarra Drug Industries, Iraq), citric acid (Evonik Degussa Ltd., India),tartaric acids (Aldrich, USA), Sodium bicarbonate, hydroxyl propyl methylcellulose (HPMC E5), (Gainland chemical company, U. K), Microcrystalline cellulose (Riedel-De-Haen AG seelze, Germany), croscarmellose sodium (Hyperchem, China).

\section{Methods}

\section{Formulation of effervescent granules of ibuprofen}

The wet granulation method was used to prepare the effervescent granules of ibuprofen [4]. The quantity of each ingredient used is shown in table 1. According to geometrical dilution, all ingredients of the formulation will be mixed thoroughly to maintain good distribution of the drug with other ingredients, and then pass the powder through sieve no 20 after that suitable amount of binding agent added the powder mixture to fabricate a moist mass. Then moisten mass was passed through sieve no. 20 to get granules. These granules were be dried at $40{ }^{\circ} \mathrm{C}$ overnight in a hot air oven.

Table 1: Formula used to prepare the effervescent granule of ibuprofen

\begin{tabular}{|c|c|c|c|c|c|}
\hline Ingredients (mg) & F1 & F2 & F3 & F4 & F5 \\
\hline Ibuprofen & 600 & 600 & 600 & 600 & 600 \\
\hline Citric acid & 217 & 217 & 217 & 217 & 217 \\
\hline Tartaric acid & 434 & 434 & 434 & 434 & 434 \\
\hline Sodium bicarbonate & 738 & 738 & 738 & 738 & 738 \\
\hline Saccharine & 15 & 15 & 15 & 15 & 15 \\
\hline Croscarmellose sodium & - & 5 & & - & 5 \\
\hline Banana powder & - & - & 5 & - & 5 \\
\hline Microcrystalline cellulose & - & - & & $\overline{5}$ & \\
\hline HPMC in alcohol $2 \%$ & $\overline{5}$ & 5 & 5 & 5 & $\overline{5}$ \\
\hline
\end{tabular}

Evaluation of effervescent granules of ibuprofen

Determination of drug content

$100 \mathrm{mg}$ of effervescent granules were weighed and added to $100 \mathrm{ml}$ of phosphate buffer solution ( $\mathrm{pH} \mathrm{6.8)} \mathrm{and} \mathrm{mixed} \mathrm{thoroughly.} \mathrm{Then}$ the solution filtered and analyzed by using a UV-visible spectrophotometer (UV-1800 shimadzo, Japan) at $260 \mathrm{~nm}$ to detect the $\%$ of drug content of ibuprofen in the prepared granules. The drug content of each sample was estimated from their previously prepared Standard curve [5]. 


\section{Fourier transforms infrared spectroscopy (FTIR) study}

FTIR spectroscopy was used to detect the compatibility between ibuprofen and other ingredients. Disc of potassium bromide at wavelength $4000-400 \mathrm{~cm}^{-1}$ was used to recorded FTIR spectra of ibuprofen, each ingredient in the formula and selected formula [6].

\section{Flowability study}

\section{Bulk density and tapped density}

Two types of density were determined (bulk density (BD) and tapped density (TD)). In a $100 \mathrm{ml}$ measuring cylinder, an appropriate amount of granules was weighted and put; then the initial volume was recorded. After that, the measuring cylinder was tapped at the height of $2.5 \mathrm{~cm}$ at 2-second intervals until no further change was noted in the volume [7]. From the equation below, bulk density and tapped density were calculated.

$$
\begin{gathered}
\mathrm{BD}=\frac{\text { granules weight }}{\text { packing volume }} \\
\mathrm{TD}=\frac{\text { granules weight }}{\text { tapped volume of the packing }}
\end{gathered}
$$

Where BD is the bulk density and TD is the tapped density

Carr's index for ibuprofen granules was measured to evaluate the bulk density and tapped density [8]. The values of Carr's index of ibuprofen granules were compared with references as shown in table 2.

$$
\text { Carr' } s \text { index }=\frac{[(\mathrm{TD}-\mathrm{BD}) * 100]}{\mathrm{TD}}
$$

Hausner's ratio of ibuprofen granules was calculated by using the equation below. Hausner's ratio which is less than 1.25 shows good flowing properties more than higher ones. Hausner's ratios which are from 1.25 to 1.6 show moderate flowing properties. Hausner's ratio which is more than 1.6 will show more cohesive powders [9].

$$
\text { Hausner' ratio }=\frac{\text { tapped density }}{\text { bulk density }}
$$

\section{The angle of repose determination}

To estimate the flow properties of ibuprofen granules, the funnel method was used to measure the angle of repose. When granular materials are poured onto a horizontal plane; a conical pile will be formed. The internal angle between the surface of the pile and the horizontal surface is known as the angle of repose. The tan of the angle of repose was measured by height $(\mathrm{H})$ of the cone and diameter of the base cone (D) [10]. The values of the angle of repose were compared with references as shown in table 3 .

$$
\operatorname{Tan} \theta=\frac{\mathrm{H}}{0.5 * \mathrm{D}}
$$

Table 2: Flow properties and compressibility index

\begin{tabular}{ll}
\hline Flow characters & Carr's index \\
\hline Excellent & $1-10$ \\
Good & $11-15$ \\
Fair & $16-20$ \\
passable & $21-25$ \\
poor & $26-31$ \\
Very poor & $32-37$ \\
Very, very poor & $>38$ \\
\hline
\end{tabular}

Table 3: Flow properties of the angle of repose

\begin{tabular}{ll}
\hline The angle of repose value & Flow properties \\
\hline$<20$ & Excellent \\
$20-30$ & good \\
3034 & passable \\
$>40$ & Very poor \\
\hline
\end{tabular}

\section{Effervescence time}

The effervescent time of ibuprofen granules was measured by adding one dose of granules to a glass containing $250 \mathrm{ml}$ of water when a clear solution is obtained the effervescent time will be recorded [11]. The arithmetic mean of triplicate readings was recorded.

\section{Dissolution study}

The dissolution study of ibuprofen granule was done by using the USP type II dissolution test apparatus. The dissolution test was performed by using a dissolution medium made of phosphate buffer with pH 6.8 and at a temperature of $37 \pm 0.5^{\circ} \mathrm{C}$ and $50 \mathrm{rpm}$. A sample of $5 \mathrm{ml}$ will be drawn every $1 \mathrm{~min}$ interval and then replenished with $5 \mathrm{ml}$ to maintain the constant volume. After that, the sample was filtered through Whitman filter paper, and then the absorbance of the sample was measured at $260 \mathrm{~nm}$. Then, the amount of drug released was calculated from a previously prepared calibration curve of ibuprofen [12].

\section{Statistical analysis}

By using Microsoft Excel 2007, the results of the investigation are given as a mean sample (of three results) \pm standard deviation (SD).

\section{RESULTS AND DISCUSSION}

The results of the flowability study are shown in table 4 . The values of bulk density were in the range of $0.45-0.51$. The tapped density values of the prepared granules were in the range of $0.52-0.59$. The values of the angle of repose were found in range 25.2-28.98. While the result of the caris index of the prepared granules was in the range of 12.1-14.03. Hausner's ratio values were found in the range of 1.13-1.16. The results indicate that all five formulas had good flow properties. The good flow properties may be attributed to the successful method of preparation by wet granulation [13].

Table 4: Flow properties of ibuprofen effervescent granules

\begin{tabular}{lllllll}
\hline Formula no. & Bulk density & Tapped density & Angle of repose & Carr's index & Hausner's ratio & Flow property \\
\hline F1 & $0.5 \pm 0.15$ & $0.57 \pm 0.12$ & $28.98 \pm 0.98$ & $12.28 \pm 0.13$ & $1.14 \pm 0.03$ \\
F2 & $0.49 \pm 0.20$ & $0.57 \pm 0.09$. & $27.9 \pm 0.16$ & $14.03 \pm 0.15$ & $1.16 \pm 0.04$ \\
F3 & $0.45 \pm 0.18$ & $0.52 \pm 0.11$ & $27.72 \pm 0.17$ & $13.46 \pm 0.18$ & $1.15 \pm 0.72$ \\
F4 & $0.51 \pm 0.08$ & $0.58 \pm 0.12$ & $25.2 \pm 0.18$ & $12.1 \pm 0.99$ & $1.13 \pm 0.11$ \\
F5 & $0.51 \pm 0.12$ & $0.59 \pm 0.13$ & $26.88 \pm 0.87$ & $13.55 \pm 0.12$ & good & good \\
\hline
\end{tabular}

$*$ Results are expressed as a mean \pm SD, $n=3$. 


\section{Compatibility study}

The results of the FTIR study are shown in fig. 1. Fig. 1 (A) represents the peaks of ibuprofen drug, it detects intense band at
$1720.56 \mathrm{~cm}^{-1}, 2956.97 \mathrm{~cm}^{-1}, 1645.33 \mathrm{~cm}^{-1}$, for $\mathrm{C}=0, \mathrm{C}-\mathrm{H}$, and $\mathrm{C}=\mathrm{C}$ respectively. Fig. 1 (B) represents the FTIR spectra of the selected formula (F5). The result demonstrates no chemical interaction between ibuprofen drug and other ingredients [14].

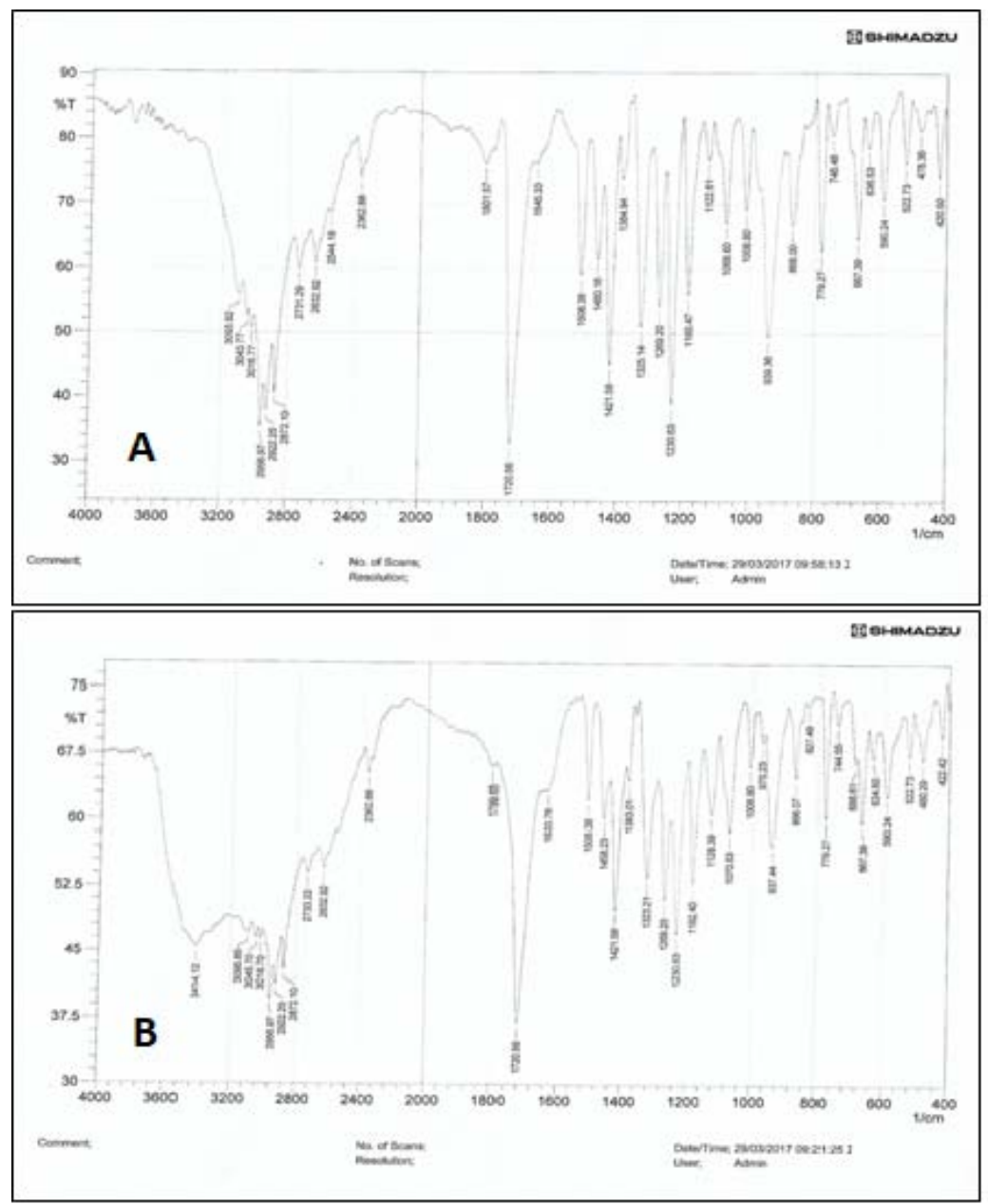

Fig. 1: Spectra of ibuprofen and the selected formula F5, where (A): IR spectrum of ibuprofen, (B): IR spectrum of selected formula F5

\section{Determination of $\%$ drug content}

The results of $\%$ of drug content were shown in table 5 . The values of $\%$ drug content were in range 90.6 $\pm 0.12-97.5 \pm 0.12$. All five formulas were qualified for the IP specification for assay of ibuprofen granules which should be not less than $90 \%$ and should not more than $110 \%$.

\section{Effervescence time determination}

The results of the effervescence time were shown in table 5 . The values of effervescence time were in the range of $80-113 \mathrm{sec}$. The resulted ranges were acceptable for this study according to USP [15].

\section{Dissolution study}

The $\%$ amount of drug released after 5 min obtained for the five formulations of effervescent granules of ibuprofen are presented in table 5. The results show that all five formulas had a good release profile within $5 \mathrm{~min}$. The improvement of ibuprofen dissolution occurs due to bursting of the granules into minute particles which was facilitated by the production of effervescence. F5 shows the highest percentage of drug released, 99.1\% within 5 min. The good release profile of F5 may be attributed to the presence of the combination of disintegrant banana powder and croscarmellose sodium $[16,17]$.

Table 5: Drug content, amount of drug released and effervescent time of ibuprofen granules

\begin{tabular}{llll}
\hline Formula & Drug content $\%(w / w)$ & Amount of drug released \% & Effervescent time (sec) \\
\hline F1 & $93.9 \pm 0.14$ & $90.2 \pm 0.12$ & $110 \pm 0.09$ \\
F2 & $95.6 \pm 0.13$ & $96.6 \pm 0.13$ & $104 \pm 0.13$ \\
F3 & $95.1 \pm 0.99$ & $95.3 \pm 0.98$ & $100 \pm 0.11$ \\
F4 & $90.6 \pm 0.14$ & $92.4 \pm 0.12$ & $113 \pm 0.13$ \\
F5 & $97.5 \pm 0.11$ & $99.1 \pm 0.1$ & $80 \pm 0.12$ \\
\hline
\end{tabular}

$*$ Results are expressed as a mean $\pm \mathrm{SD}, n=3$. 
In comparison with other studies used croscarmellose sodium and banana powder as a disintegrant, the results show the same enhancing effect of drug release of tramadol, meloxicam, and ibuprofen $[18,19]$. That is the ability of both croscarmellose sodium and banana powder to act as disintegrates [20-22].

\section{CONCLUSION}

Ibuprofen was prepared and evaluated successfully as effervescent granules by wet granulation method. Effervescent granules of ibuprofen were well prepared by using citric acid, tartaric acid, sodium bicarbonate, saccharine, croscarmellose, banana powder, microcrystalline cellulose and HPMC in ethanol alcohol.

\section{AUTHORS CONTRIBUTIONS}

All the author have contributed equally

\section{CONFLICT OF INTERESTS}

Declared none

\section{REFERENCES}

1. Aulton ME. Pharmaceutics: the science of dosage form design. $2^{\text {nd }}$ ed. New York: Churchill Livingstone; 2002.

2. Diy ASM, Thom NY. Formulation and evaluation of metronidazole effervescent granules. Int J Pharm Sci Res 2018;9:2525-9.

3. Parikh, Dilip M. Effervescent granules. Handbook of pharmaceutical granulation technology. Edn 3. Informa Healthc; 2005. p. 365-84.

4. Amidon GL, Lennernas H, Shah VP, Crison JR. A theoretical basis for a biopharmaceutic drug classification: the correlation of in vitro drug product dissolution and in vitro bioavailability. Pharm Res 1995;12:413-20.

5. Lachmann L, Liberman H, Kanig J. The theory and practice of industrial pharmacy. Edn 3. Verghese Publishing House, Bombay; 1991. p. 320-1.

6. Bhosale AV, Hardikar SR, Patil N, Patel U, Sumbe Y, Jagtap R. Formulation and in vitro evaluation of microbially triggered ibuprofen. Int J PharmTech Res 2009;1:328-33.

7. S Patel, Natvarlal M Patel. Development of directly compressible co-processed excipient for dispersible tablets using 32 full factorial design. Int J Pharm Pharm Sci 2009;1:125-48.

8. Senthil P, Suresh Kumar CH, Narasimha Raju, S Mohideen. Formulation and evaluation of gastric oral floating tablet of glipzide. Int J Biol Pharm Res 2010;1:108-13.
9. Wells J. Pharmaceutical preformulation: the physicochemical properties of drug substances. In: Aulton M. The science of dosage form design by Michael. $2^{\text {nd }}$ ed. Churchill livengstone; 2004. p. 133-4.

10. Kaerger S, Edge S, Price R. Influence of particle size and shape on flowability and compatibility of binary mixtures of paracetamol and microcrystalline cellulose. Eur J Pharm Sci 2004;22:173-9.

11. Sandhya S, Gowthami G, Vinod KR, VidyaSravanthi E, Saikumar $\mathrm{P}$, Rao Knv, et al. Formulation and evaluation of herbal effervescent granules incorporated with limnophila indica extract for bacillary dysentery. Ann Bio Res 2012;3:63-72.

12. R Margret chandira, Debjit Bhowmik, Rahul Yadav, B Jayakar, K Sampath Kumar. Formulation and evaluation of the oral tablets ibuprofen. Pharma Innovation 2012;1:32-42.

13. Abolfazl Aslani, Fatemeh Fattahi. Formulation characterization and physicochemical evaluation of potassium citrate effervescent tablet. Adv Pharm Bull 2013;3:217-25.

14. Eter lakin. Infrared and Raman spectroscopy. $1^{\text {st }}$ edition; 2011.

15. The United State Pharmacopeia (USP), 30, NF28, USA: The United State Pharmacopeia Convention Inc; 2010.

16. RB Saudagar. Formulation and characterization and evaluation of mouth dissolving tablet of lisinopril by using dehydrated banana powder as a natural polymer. WJIPR 2015;4:763-74.

17. Nayyar Parz, Pramod Kuma. FDA-Approved natural polymers for fast-dissolving tablets. J Pharm 2014;1-6. http://dx.doi.org/10.1155/2014/952970.

18. Shah SJ. Formulation and evaluation of mouth dissolving tablet of tramadol hydrochloride. AJPCR 2013;6:31-6.

19. J Ham, S Parthiban, A Vikneswari, GP Sentil kumar, T Tamiz Mani. Formulation and evaluation of orodispersible liquisolid compacts of meloxicam using banana powder as natural super disintigrentes. AJPRS 2015;3:25-38.

20. Gopinath E. Evaluation of musa acuminate fruit as a natural super disintegrant for tablet formulation. AJPCR 2018;11:16771.

21. Hiola R, Tunadi R. Development of effervescent granules of corn milk supplemented with probiotic lactobacillus strain shirota. Int J Appl Pharm 2018;10:71-5.

22. Masaad AMA, Shayoub MEA, Maghrabi IA, Masaad NMA. In vitro-in vivo correlation study of a newly formulated effervescent ciprofloxacin tablets with reference tablets. Int J Curr Res Chem Pharm Sci 2016;3:1-12. 